\title{
EFFECT OF ALUMINIUM OXIDE NANOPARTICLES ON EMISSIONS OF DIESEL ENGINE USING MICRO-ALGAE BIO-DIESEL
}

\author{
A. PHANIDEEPTHI ${ }^{1}$, J. PRABAKARAN ${ }^{2}$, A. P .SATHIYAGNANAM ${ }^{3}$, K. RAMANAIAH $^{4}$ \\ \& A. V. RATNA PRASAD 5 \\ 1,4, 5 Department of Mechanical Engineering, VR Siddhartha Engineering College, Vijayawada, \\ Andhra Pradesh, Inda \\ ${ }^{2,3}$ Department of Mechanical Engineering, Annamalai University, Chidambaram, Tamil Nadu, India
}

\begin{abstract}
The present work deals the influence of $\mathrm{Al}_{2} \mathrm{O}_{3}$ Nano particles one missions of single cylinder diesel engine using the micro algae biodiesel. Micro algae bio-diesel blend was produced by mingling the $20 \%$ micro algae with the $80 \%$ diesel (B20) in volumetric approach. The $\mathrm{Al}_{2} \mathrm{O}_{3}$ Nano particles were distributed in B20 bio-diesel using an instrument called ultrasonicator. The result reveals that there was a reduction of emissions due to the mixing of Nano particles in micro algae bio-diesel blend B20.
\end{abstract}

KEY WORDS: Emission, $\mathrm{Al}_{2} \mathrm{O}_{3}$, Nanoparticles, Micro Algae Bio-Diesel \& Ultrasonicator

Received: Jun 06, 2020; Accepted: Jun 26, 2020; Published: Jun 30, 2020; Paper Id.: IJMPERDJUN2020173

\section{INTRODUCTION}

For the reduction of emissions as well as global warming, biodiesels are added in the fuels. The addition of Nano particle also reduce emissions to some extent, sine it leads to clean burning of fuel. However usages of biodiesel have many difficulties such as higher viscosity, lower heat capacity and engine durability. There are many kinds of biodiesels such as jatropa oil, waste cooking oil, animal facts , Karajan oil, sesame oil, mahuva oil, soybean oil, corn oil, olive kernel oil , micro algae etc. And their methyl esters. Soya, canola, palm produces 4501, 1200L, and 60001L biodiesel per hectare per year. Researchers predict that 90000L of micro algae biodiesel could be produced per hectare. Oil squeezed used for biodiesel and rest for biomass [1]. Micro algae biodiesel are nontoxic, highly biodegradable, containing no sulphur content and remaining is used as soil fertilizer [2]. The SFC and BTE of micro alge biodiesel were lower than automobile gas oil. All samples given very close density among them and lower than AGO (automobile gasoline oil) [3]. Under good conditions green algae can double its biomass in less than $24 \mathrm{~h}$ and having higher lipid content over 50\%, B20 blend having max BTE, lower smoke density, and lower NOx values for all blends[4]. CalopyllumInopyllum biodiesel mixed with $\mathrm{TiO}_{2}$ nanoparticles at 40ppm, the $\mathrm{CO}$ emissions was reduces by $23 \%$ for $\mathrm{B} 2040 \mathrm{TiO} 2$ fuel and others are increased $[5,6]$. The JBD30A30C fuel having 31\% BTE while neat diesel having 32\%, the reduction of NO, CO and UBHC are decreased by 13\%, 60\%, and 33\% for JBD30A30C fuel when compared to neat diesel [7]. Azolla algae with $\mathrm{TiO}_{2}$ Nano particles mixed with different proportions of 25, 50, 75,100ppm and tested BSFC had decreased at 23.53\% for B20+100fuel, B20+100 fuel having reduction of $57.30 \% \mathrm{CO}, 12.97 \% \mathrm{HC}$ emissions, NOx emissions are increased at $9.16 \%$ for B20+100 fuel compared to B20 blend[8]. In this research work the micro algae biodiesel is prepared by using the transesterification process. With the help of magnetic stirrer, the blend B20 was prepared by mixing $20 \%$ biodiesel 
with $80 \%$ diesel in volumetric basis. $\mathrm{Al}_{2} \mathrm{O}_{3}$ Nano particles were dispersed into the $\mathrm{B} 20$ blend with dosage of 50 , and 100ppm and named as B20+A50 and B20+A100 fuel samples. Ultrasonicatoris used for the Scattering of Nano particles with fuel for 45 min to maintain the consistent blends.

\section{MATERIALS AND METHODS}

The micro algae biodiesel blend B20 was prepared by using $20 \%$ biodiesel with $80 \%$ diesel using the transesterification process. $\mathrm{Al}_{2} \mathrm{O}_{3}$ Nano particles were dispersed into the $\mathrm{B} 20$ blend with dosage of 50, and 100ppm and named as B20+A50, and B20+A100 fuel samples. Spreading of Nano particles with fuel are prepared with ultrasonicator for 45 min to maintain the consistent blends. The specifications of Nano particles shown in table.1

Table 1: Specification of Nano Particle

\begin{tabular}{|l|l|}
\hline \multicolumn{1}{|c|}{ Item } & \multicolumn{1}{|c|}{ Specification } \\
\hline Manufacturer private ltd & $\begin{array}{l}\text { Nano wings } \\
\text { Khammam }\end{array}$ \\
\hline Chemical name & Aluminum $\left(\mathrm{Al}_{2} \mathrm{O}_{3}\right)$ \\
\hline Molecular weight & $101.96 \mathrm{~g} / \mathrm{mole}$ \\
\hline Average particle size diameter & $50-200 \mathrm{~nm}$ \\
\hline Specific surface area & $32 \mathrm{~m}^{2} / \mathrm{g}$ \\
\hline Appearance & white powder \\
\hline
\end{tabular}

Table 2: Properties of Fuel

\begin{tabular}{|l|c|c|c|c|c|}
\hline \multicolumn{1}{|c|}{ Properties } & $\begin{array}{c}\text { ASTM } \\
\text { Standards }\end{array}$ & B20 & B20+A50 & B20+100 & Diesel \\
\hline $\begin{array}{l}\text { Density } \\
\text { @ } 15^{\circ} \mathrm{C} \\
\left(\mathrm{kg} / \mathrm{m}^{3}\right)\end{array}$ & $\mathrm{D} 1298$ & 852 & 856 & 861 & 745 \\
\hline $\begin{array}{l}\text { Kinematic } \\
\text { viscosity } \\
\text { @ } 40^{0} \mathrm{C} \\
(\mathrm{cSt})\end{array}$ & $\mathrm{D} 88$ & 4.6 & 4.7 & 4.8 & 3.8 \\
\hline Flash point ${ }^{0} \mathrm{C}$ & $\mathrm{D} 93$ & 109 & 112 & 121 & 52 \\
\hline Fire point $\left({ }^{\circ} \mathrm{c}\right)$ & $\mathrm{D} 93$ & 115 & 121 & 132 & 62 \\
\hline $\begin{array}{l}\text { Calorific value } \\
(\mathrm{MJ} / \mathrm{kg})\end{array}$ & $\mathrm{D} 240$ & 4.2 & 4.3 & 4.6 & 4.3 \\
\hline
\end{tabular}

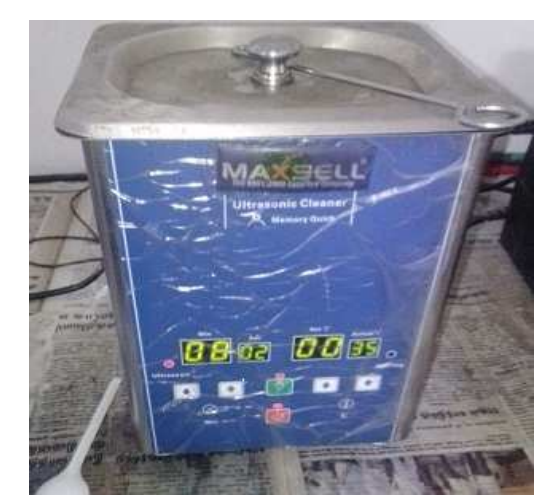

Figure 1: Ultrasonicator.

The aluminum oxide Nano particles are mixed with biodiesel with desired proportions 50 ppm and 100ppm by means of ultrasonicator. The mixture is used quickly without any delay because the Nano particles can be settle down at 
the bottom of the bottle.

\section{Experimental Procedure}

The detailed experimental procedure was same as discussed in the previous published article [5]

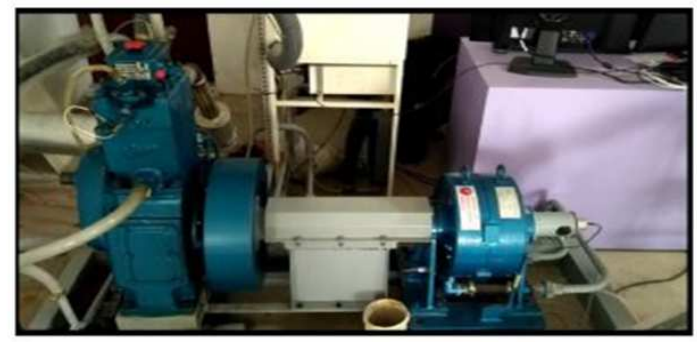

Figure 2: Experimental Set up.

\section{RESULTS AND DISCUSSIONS}

\section{CO Emissions}

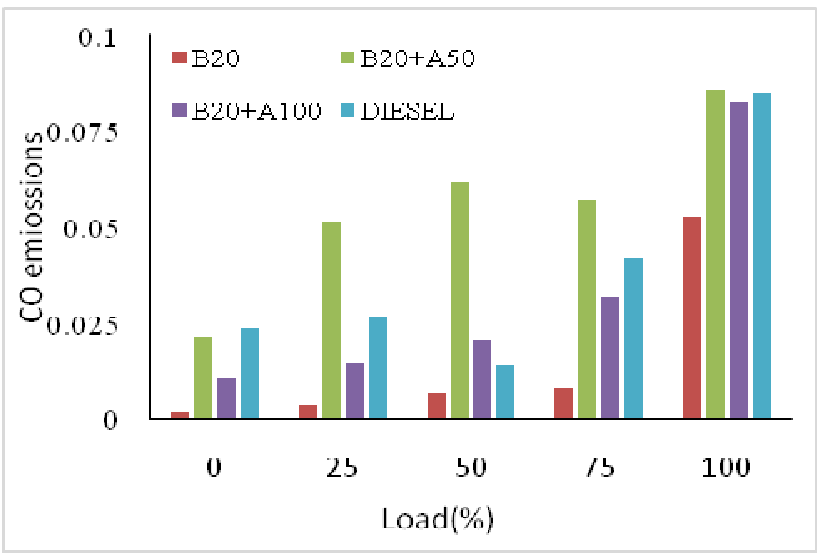

Figure 3: Change of CO Emissions.

Figure 3 illustrates the change of $\mathrm{HC}$ emissions as the load changes. Co emissions decresed due to the addition of Nano particles (B20+ A 100) irrespective of load on the engine. The same trend was observed in the literature [2]. This is because of delay in ignition period was reduced due to raise in chemical reaction.

\section{HC Emissions}

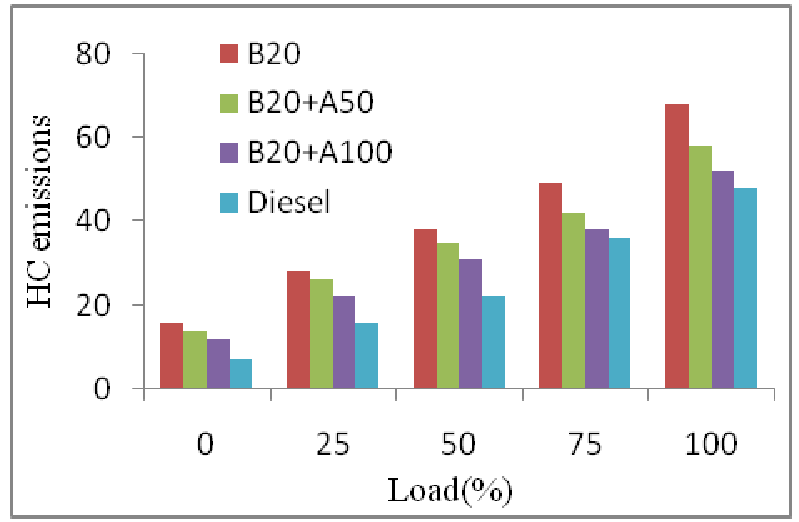

Figure 4: Change of Hydro Carbon Emissions. 
Figure 4 illustrates the change of $\mathrm{HC}$ emissions as the load changes. . It was pragmatic that as the content of Nano particles increased the hydro carbon emissions were decreased. Among all blends the minimumhydro carbon emissions were pragmatic for B20+A100 at maximum load conditions. Nanoparticles enhance the combustion process, therefore ignition delay shorted [2].

\section{NOX Emissions}

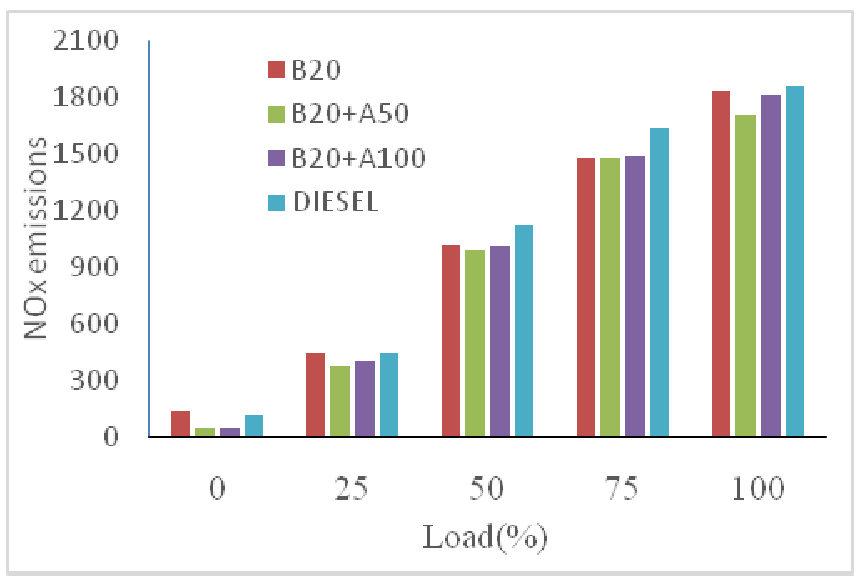

Figure 5: Change of NOx Emissions.

Figure 5 illustrates the change of NOx emissions with the load. The NOx emissions are increased with the increased in dosage of Nano particles. For each load, NOx emissions are reduced than B20sample. As perceived that the NOx emissions of B20 and B20+50 blends are 1825 and 1704ppm and diesel having 1857ppm at maximum load. This is owing to the formation of chain reactions involving nitrogen and air and in complete combustion of fuel [7].

\section{Smoke Opacity}

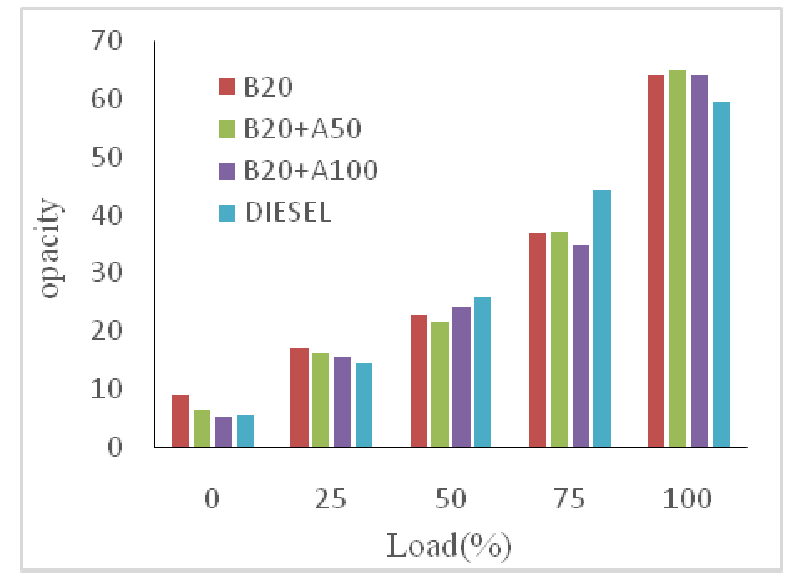

Figure 6: Dependence of Smoke Opacity.

Figure 6 illustrates the change in load with the smoke opacity. The smoke opacity decreased as content of Nano particles increased in the mixture. The smoke opacity values of B20+50, and B20+100 are 64.8, and 63.9, and B20 fuel having 63.9, is greater than the diesel fuel is 59.3 respectively. Similar trend was observed in the literature [8].

\section{CONCLUSIONS}

- The CO emissions are decreased by $2.3 \%$ for B20+100 fuels than the diesel. The CO emissions are decreased 
$3.4 \%, 10.7 \%$ for B20+A100fuel than theB20+A50 and B20 fuel.

- The CO emissions are increased by $7.69 \%$ for B20+100 fuels than the diesel. The CO emissions are decreased $6.45 \%, 23.52 \%$ for B20+A100 fuel than theB20+A50 and B20 fuel.

- The NOx emissions are reduced by $2.8 \%$ for B20+100 fuels compared to diesel. This phenomenon is also due to the addition of 50ppm of nanoparticles and increased further addition of nanoparticles. This is due to having the nitric radical's changes into the $\mathrm{N}_{2}$.

- The opacity increased by $7.19 \%$ for B20+100 fuels than the diesel. The opacity is increased for B20+A50 fuel than theB20+A100 and B20 fuel.

\section{REFERENCES}

1. Nirupama Mallick, Shovon Mandal, Amit Kumar Singh, Moumita Bishai and Archana Dash., "Green microalga Chlorella vulgaris as a potential feedstock for biodiesel”, J Chem Techno Biotechnol., vol.87, no.1, (2012); pp. 137-145.

2. Saddam H. Al-lwayzy, TalalYusaf and Raed A. Al-Juboori, "Biofuels from the Fresh Water Microalgae Chlorella vulgaris (FWM-CV) for Diesel Engines”, Energies ,vol.7,no. 3,(2014); pp.1829-1851.

3. Adhoni, Shakeel Ahmed, Shanthanu M. Raikar, and C. T. Shivasharana. "Bioremediation of Industrial Effluents with Heavy Metals using Immobilised Microalgae." International Journal of Applied and Natural Sciences (IJANS) 7.5 (2018): 67-84.

4. Eloka-Eboka A.C and Inambao F.L, "Performance and Emission Profile of Micro-Algal Biodiesel in Compression Ignition Engine”, International Journal of Engineering Research in Africa,Vol. 30,(2017), pp. 110-124.

5. Tom Varghese, Jesu Raj, E. Raja and C. Thamotharan., "Performance and Emission Testing on Algae Bio Fuel using Additives”, International Journal of Engineering and Advanced Technology (IJEAT), Vol.4,no.5,(2015),pp. 28-33.

6. Tatikonda, Nambaya Charyulu, and P. Naveenchandran. "The Behaviour of a Compression Ignition Engine Under the Influence of Diesel and Microalgae Biodiesel Blends." International Journal of Mechanical and Production Engineering, Research and Development 9.4 (2019): 447-456.

7. Mundhe, Raju G. "Renewable Energy Source Algae Biodiesel as Alternative Fuel." (2017).

8. Praveen A, G. Lakshmi Narayana Rao, B. Bala Krishna., "Performance and emission characteristics of diesel engine using Calophyllum Inophyllum biodiesel blends with $\mathrm{TiO}_{2}$ Nano additives and EGR", Egyptian Journal of Petroleum vol.27,no.4,(2017),pp.731-738.

9. Singh, Sanjay, and M. Prabhahar. "Experimental Investigation of Performance and Emission Characteristics Using Chlorella Algae Bio Diesel as Alternative Fuel."International Journal of Mechanical and Production Engineering Research and Development (IJMPERD) 9. 6, Dec 2019, 319-334

10. SonerGumus, HakanOzcan, Mustafa Ozbey, Bahattin Topaloglu., “Aluminum oxide and copper oxide Nano diesel fuel properties and usage in a compression ignition engine”, Fuel 163 (2016), pp.80-87.

11. Prabu A, R.B. Anand, "Emission control strategy by adding alumina and cerium oxide nano particle in biodiesel", Journal of the Energy Institute, vol.89, no.3, (2016),pp.366-372.

12. Krishna, MVS Murali, and K. Vamsi Krishna. "Studies on Exhaust Emissions of Di Diesel Engine with Low Grade LHR Combustion Chamber Fuelled with Linseed Biodiesel." International Journal of Mechanical Engineering (IJME) 3.6 (2013): 63-72. 
13. Bose Narayanasamy, Nagarajan Jeyakumar, "Performance and emission analysis of methyl ester of Azolla algae with TiO2 Nano additive for diesel engine”, Energy Sources, Part A: Recovery, Utilization, and Environmental Effects, vol.41,no.12,(2018),pp.1434-1445. 